\title{
Relationships Between User Knowledge Sharing in Virtual Community with Community Loyalty and Satisfaction
}

\author{
Jiemei Zhang (D) \\ Yuejie $\mathrm{Ma}{ }^{1}{ }^{1}$ \\ Bei Lyu (D) ${ }^{1-4}$
}

'Business School, Henan University, Kaifeng, 475004, People's Republic of China; ${ }^{2}$ School of Economics and Management, Huaibei Normal University, Huaibei, 235000, People's Republic of China; ${ }^{3}$ Leeds University Business School, University of Leeds, Leeds, LS2 9JT, UK; ${ }^{4}$ Chinese Graduate School, Panyapiwat Institute of Management, Nonthaburi, III20, Thailand
Correspondence: Bei Lyu

Huaibei Normal University, No. 100, Dongshan Road, Xiangshan District,

Huaibei, Anhui Province, 235000, People's

Republic of China

Email peter1983123@hotmail.com
Background: Ubiquitous social media usage makes virtual communities important platforms for people to exchange knowledge and information. The long-term sustainable operation of the virtual community depends on the scale and activity of users in the virtual community. However, in existing virtual communities, the number of easily lost users far exceeds the number of loyal users with the high frequency of knowledge sharing, thus there is a community management need to improve the frequency of knowledge sharing and user loyalty.

Methods: Based on the social capital theory and social exchange theory, this paper constructs a model of the influence of knowledge sharing on the loyalty and satisfaction of users in a virtual community and undertakes an empirical analysis based on survey data from 533 members of virtual communities.

Results: The results showed that trust, reciprocity, and reputation positively affected the quantity and quality of knowledge sharing, while social connectedness only positively affected the quantity of knowledge sharing; the quantity and quality of knowledge sharing positively affected community loyalty and community satisfaction.

Conclusion: This study takes the knowledge sharing of virtual community users as a new starting point to cultivate loyal consumers. It has important theoretical and practical value to improve the satisfaction of community users, cultivate loyal community users, and promote the knowledge sharing of members.

Keywords: social capital, external motivation, knowledge sharing, community satisfaction, community loyalty

\section{Introduction}

The development of Internet communication technology has completely changed the way people live and communicate, virtual activities, digital networks, mobility and interpersonal relationships in the virtual world add color to human life. ${ }^{1}$ Virtual community is a place where one can find and speak to others with similar interests. ${ }^{2}$ Promoted by the requirements for information to a great extent, ${ }^{3}$ users participating in virtual communities can share information and experiences, expressing their views and opinions on products, services, and general reflections, as well as seeking information relating to products or problems through the network platform.

Knowledge sharing refers to the process of spreading various resources among individuals participating in specific activities. ${ }^{4}$ When users find that a virtual community meets their demands, can bring themselves a pleasant experience, or can 
give themselves rich and high-quality knowledge or resources, they tend to be more satisfied with the community and are more willing to join the community. Over the long term, the frequent sharing of colorful and useful knowledge by community users can improve user satisfaction through the rapid responsiveness of community users to answer queries, ${ }^{5}$ helping enterprises disseminate the information to the targeted public, promoting products and establishing a good brand image. The satisfaction and loyalty of community users is an important factor affecting the healthy development of communities and enterprises. However, Knowledge sharing is a voluntary behavior and there must be some behavioral motivation to involve in the act. ${ }^{6}$ Therefore, how to improve the knowledge-sharing frequency of users in the virtual community, improve their community loyalty and satisfaction, and cultivate loyal users are the problems that need to be solved in the virtual community.

This study uses social capital and social exchange theory to construct a theoretical framework for user knowledge sharing in virtual communities. With the context of social capital and external motivations, this study explores the key influencing factors of knowledge sharing in virtual communities and their impact on community satisfaction and community loyalty. In previous studies, When scholars study consumer knowledge sharing in virtual communities, they are keener to explore only the antecedent variables that affect knowledge sharing behavior. ${ }^{7,8}$ Few scholars discuss users' impact of knowledge-sharing behavior in virtual communities on consumer community loyalty and community satisfaction. In addition, they tend to measure knowledge sharing as a whole variable, paying more attention to the quantity of knowledge sharing, and ignoring the quality of knowledge sharing. ${ }^{8,9}$ Research on loyalty and consumer satisfaction is also mostly concentrated in the traditional organizational environment. Therefore, in the specific scenario of the virtual community, exploring the influencing factors of knowledge sharing behavior and the impact of knowledge sharing behavior on user community loyalty and community satisfaction can lay a theoretical foundation for the research of consumer community loyalty. The article provides guidance, providing a new idea for companies and virtual community managers to improve consumer loyalty. The following three questions are answered in this study:

(i) What is the relationship between social capital, external motivation, and knowledge sharing level? (ii) What is the relationship between knowledge sharing level, community loyalty, and community satisfaction?

(iii) How does the knowledge sharing level play a mediating role in the relationship between social capital, external motivation, community loyalty, and community satisfaction?

\section{Literature Review}

\section{Knowledge Sharing in Virtual Community}

A virtual community is a platform for users to exchange knowledge for various purposes. ${ }^{10}$ Autio et al observed that virtual communities based on the Internet platform have provided a place for communication between individuals and entities with common interests. ${ }^{11}$ Virtual communities do not have the time synchronization and geographical limitations necessary for traditional face-to-face communication, making them more conducive to a greater volume of communication among more people, on an anytime, anywhere basis. The more active members a virtual community has, the more frequent the knowledge flow between its users is. The broad outlines of pertinent dynamics on virtual communities have been identified since the early years of mass social media and e-commerce usage. For instance, McLure and Farraj found that community users shared their product experience through a series of activities facilitated by the community platform. ${ }^{12}$ Ridings et al concluded that community users had the requirements for information acquisition, knowledge, and experience sharing, personal friendship, entertainment, and community tool utilization. ${ }^{13}$ Cai and Shi thought that virtual communities break the tradition that only a few authoritative institutions release knowledge. ${ }^{14}$ The production and dissemination of knowledge are left to the users in the community. Each registered user can share information and knowledge in the community. van den Hoof and de Ridder Jan observed that knowledge sharing between individuals made knowledge absorbable, understandable, and applicable by others. $^{15}$

Hau and Kim defined knowledge sharing as the voluntary provision of knowledge by virtual community users to help other community members to solve problems. ${ }^{16} \mathrm{Kim}$ and Park defined knowledge sharing as the process of exchanging task information, expert knowledge, and feedback on programs or products to create new knowledge or ideas, deal with problems and achieve common goals. ${ }^{17}$ Zheng explained that knowledge sharing is the conscious 
behavior and decision of individuals voluntarily externalizing or disseminating knowledge (compilation, display, description, etc.), and the ability of knowledge receivers to internalize or absorb knowledge (learning while doing, reading, interpretation, etc.). ${ }^{18}$ The result of knowledge sharing is that knowledge will be shared by two or more parties. The most researchers have focused on knowledge sharing quantity, but ignored its quality. Enterprise managers make decisions and take actions by depending on information and knowledge stock, so an enterprise needs to obtain high-quality information and knowledge stock, especially when the enterprise is operating in an environment with high uncertainty or fuzziness. Therefore, the quantity and quality dimensions of knowledge sharing are considered in this paper respectively in terms of the frequency of knowledge sharing activities participated by knowledge sharing subjects, and the authenticity and accuracy of knowledge shared.

\section{Social Capital}

Social capital is an influential concept that evolved from New Economic Sociology. Nahapiet and Ghoshal classified three dimensions of social capital. ${ }^{19}$ (i) The structure dimension describes the overall pattern of social connectedness between individuals in a social system. It is mainly measured by social connectedness in providing the possibility for individuals to obtain resources, in which regard social connectedness refers to the relationship between community users. Generally speaking, based on the impact of social connectedness on the frequency and interactions of information exchange between users, stronger social connectedness enables stronger interactions between users and a higher frequency of information exchange. (ii) The relationship dimension describes the interrelations between people in the social network that can be conducive to individual behavior. It is mainly measured by the trust. Fukuyama, a Japanese-American scholar, posited that social capital theory, based on social trust, assumes the expectation of normal, honest, and cooperative behavior among users in a community. (iii) The cognition dimension, based on which social capital is used to describe the resources involved in terms of common language, shared goals and shared culture to provide the expression, interpretation, and a meaning system of common understanding among different actors in a network. It focuses on the impact of interrelations and interactions between people in terms of the quality and quantity of knowledge sharing. Community loyalty and satisfaction, social connectedness, and trust are used in this study to explore the impact of social capital on knowledge sharing.

Chang and Chuang described social capital as the sum of assets or resources embedded in individuals, communities, and networks, including social networks. ${ }^{20}$ Kwon and Adler defined social capital as the available goodwill associated with individuals and teams enabling them to access potential resources through social networks. ${ }^{21}$ The positive impact of social capital on the knowledge sharing of online community users has been demonstrated. Based on a systematic analysis, Fisher pointed out that social capital is beneficial to some individual behaviors as a kind of social structure resource owned by individuals, and the achievement of information exchange based on communication between individuals forms common goals and expectations among groups. ${ }^{22}$

\section{Reciprocity and Reputation Motivations}

With exchange behavior being the primordial social behavior of human beings according to social exchange theory, all social activities formed by people's actions based on cost and benefit measurement are regarded as an exchange. The motivations of reciprocity and reputation as the rewards for individual participation in social exchange are emphasized by research institutions. Feng and Ye considered reciprocity to be a kind of conditional income, whereby people expect to be helped in their efforts. ${ }^{23}$ In knowledge-sharing in the virtual community, reciprocity refers to the perception of both parties in the virtual community that their knowledge sharing communication comprises a mutual and fair exchange. In other words, those who impart knowledge do so in the belief that they will have the satisfaction of knowledge acquisition in the future, as a reasonable quid pro quo expectation of their current knowledge contribution.

As the basis of social interaction, social exchange is to obtain valuable resources. The basis for individual participation in social interaction is the expectation of gaining some benefits, such as reputation. Hsu and Lin believed that a person could improve his image by contributing knowledge. ${ }^{24}$ Choi et al also thought that people's desire for social approbation would encourage them to share knowledge. ${ }^{8}$ As the influencing factor and driving force of behavior, motivation promotes individual behavior to a certain extent. It is thus clear that reciprocity and reputation are important external motivations of virtual community users, which can promote them to actively share ideas and knowledge. 


\section{Virtual Community Loyalty and Satisfaction}

Virtual community loyalty is the extension of traditional customer loyalty. Wang and Liu considered that customer loyalty comprises the willingness of users to continue to purchase products and services after they accept the products or services provided by the company. ${ }^{25}$ López Sánchez et al pointed out that the behavioral component of loyalty pertains to repeat purchases, while the attitudinal component concerns positive brand reputation and price tolerance. $^{26}$ The simultaneous existence of higher behavior and attitude orientations can form real loyalty.

Ryu and Suh thought that users' attitudes towards the service provided by the community and their sense of belonging to the community were two key factors affecting their loyalty. ${ }^{27}$ According to the exploration of Koh and Kim on the impact of knowledge-sharing behavior on virtual community loyalty from the perspective of e-business, the loyalty of users to the community can be formed by their sense of community, driven by knowledge-sharing behavior in the virtual community. ${ }^{28}$ Virtual community loyalty in this study refers to the willingness of users to repeatedly browse the website and recommend it to others, including attitudinal and behavioral loyalty to the virtual community.

Cardozo first introduced the concept of customer satisfaction in the field of marketing. ${ }^{29}$ Ratnasari et al hold that customer satisfaction is the cognitive state of full or insufficient return after customers pay the purchase cost. ${ }^{30}$ User satisfaction refers to the sensation state generated from the comparison between the performance of products and services relative to needs and expectations. $^{31}$ Based on "demand-satisfaction", Oliver et al defined user satisfaction as a psychological response after the satisfaction of user needs and a subjective judgment of the degree to which the purchased products and services need to be satisfied. ${ }^{32}$ Michna empirically proved that knowledge sharing was an important driving force for customer satisfaction. ${ }^{33}$ User satisfaction with the virtual community in this study refers to the inner emotional and psychological response of users after the utilization and understanding of the virtual community.

\section{Research Hypotheses}

\section{Social Capital and Knowledge Sharing Level}

Social connectedness refers to the relationship between community members. The relationships between community users form a network, through which users transfer information, ideas, and other resources. Social interaction (network relationship) provides a channel for the flow of information and resources, ${ }^{34}$ facilitating knowledge sharing. ${ }^{35}$ The more interaction there is between users, the higher the frequency of knowledge exchange. Social connectedness is the channel of information exchange between members. The stronger the interaction between a person and other members, the higher the frequency of information exchange between members. When there is a strong connection between network users, knowledge sharing is relatively easy to achieve and maintain. Based on these considerations, the following hypotheses are proposed:

H1a: Social connectedness has a positive impact on knowledge sharing quantity.

H1b: Social connectedness has a positive impact on knowledge sharing quality.

Generally, trust pertains to expectations, beliefs, and confidence in certain outcomes. Chow and Lai found that trust was a necessary condition for people to share knowledge on the Internet. ${ }^{36}$ The more trust there is between knowledge- sharing participants, the more willing they are to communicate with each other. ${ }^{36}$ This kind of trust atmosphere is very important for knowledge sharing. Ridings et al reported that user trust in the ability and integrity of others directly affects willingness to contribute and acquire knowledge. ${ }^{13}$ Blau proposed that trust could maintain exchange relations, which in turn could improve the quality of knowledge sharing. ${ }^{37}$ Chang and Chuang demonstrated that the building of a high trust relationship could promote people to more actively participate in social communication and cooperative interaction. ${ }^{20}$ Interpersonal trust is vital to the creation of a knowledge sharing atmosphere. In the environment of mutual trust, the cost of knowledgesharing will be relatively low, because people think that the shared knowledge will not be abused by others. Conversely, weak general trust leads to knowledge sharers perceiving a higher cost of sharing, due to the possible inappropriate use of their knowledge by others. Based on this, the following hypotheses are proposed:

H2a: Trust has a positive impact on knowledge sharing quantity.

$\mathrm{H} 2 \mathrm{~b}$ : Trust has a positive impact on knowledge sharing quality. 


\section{External Motivation and Knowledge Sharing Level}

Given that reciprocity is the basic norm of social exchange, personal knowledge sharing in virtual communities should be encouraged and promoted, and not be left only to spontaneous development. Virtual community members share knowledge based on personality characteristics and their willingness to express their feelings. If there is an insufficient reciprocal reward, many members may be reluctant to actively share brand knowledge, particularly those who are introverted, perceive that they are disliked, or who do not feel confident in expressing themselves. Based on research concerning online health communities, Zhang et al divided community members into health professionals and ordinary users, and their empirical research found that reciprocity had a positive effect on the knowledge sharing intention of both groups. ${ }^{38}$ Empirically studying 492 respondents from a large knowledgeintensive enterprise, Rode found that reciprocity could drive employees to share knowledge on the virtual community platform. ${ }^{39}$ Choi et al noted that reciprocity had a positive impact on knowledge sharing within the community. ${ }^{8}$ Reciprocity is expected by participants in the virtual community to prove the value of time and efforts they spend in knowledge contribution, which can comprise a perceived benefit for knowledge contributors, who expect to recoup their contributions with the help of others in the future. Therefore, the following hypotheses are proposed:

H3a: Reciprocity motivation has a positive impact on knowledge sharing quantity.

$\mathrm{H} 3 \mathrm{~b}$ : Reciprocity motivation has a positive impact on knowledge sharing quality.

Individual participation in social exchange is based on the expectation of some social rewards (such as identity, status, and respect). For individuals, the more favorable comments they got in the past, the more information they will share with other users in the community in the future. Wang and Fesenmaier proved that virtual community users could improve their status in the community (including winning praise, reputation, and prestige) by making contributions to others, such as publishing a post with great content, providing high-quality information, and helping other users, etc. ${ }^{40} \mathrm{Lu}$ and Yang used 36 valid samples from Baidu knowledge, the largest online Q\&A community in
China. The results showed that the external motivation to gain an online reputation had a significant impact on the quantity and quality of knowledge sharing. ${ }^{41}$ Personal motivations promote the possible occurrence of knowledge sharing. Therefore, the following hypotheses are proposed:

H4a: Reputation motivation has a positive impact on knowledge sharing quantity.

H4b: Reputation motivation has a positive impact on knowledge sharing quality.

\section{Knowledge Sharing Level and Community Loyalty and Satisfaction}

As the basis for the survival and development of the virtual community, knowledge sharing behavior significantly affects the virtual community. Koh and Kim studied the impact of knowledge sharing on community loyalty from the perspective of e-commerce. ${ }^{28}$ Their results showed that virtual community knowledge sharing behavior engendered a sense of community among users, fostered organizational citizenship behavior, and increased loyalty to the community, which brought transactions for virtual communities and related e-commerce websites. Yao et al found that there was a significant positive correlation between knowledge sharing and virtual community loyalty through the field survey of 222 virtual community members. $^{42}$ They concluded that knowledge sharing among participants became the key to attract and retain virtual community consumers. If virtual communities could provide high-quality information to users, they would be more likely to be recognized by users and attract new users. ${ }^{43}$ Therefore, the following hypotheses are proposed:

H5a: Knowledge sharing quantity has a positive impact on community loyalty.

$\mathrm{H} 5 \mathrm{~b}$ : Knowledge sharing quality has a positive impact on community loyalty.

Essentially, the user satisfaction of the virtual community is a subjective evaluation of the services provided by the virtual community. Rubera and Kirca proved the vital importance of knowledge sharing to the improvement of customer satisfaction. ${ }^{44}$ Lin et al also verified the active role of the information quality of the network community in user satisfaction. These studies indicated that reliable, immediate, authoritative, and relevant high-quality 


\begin{tabular}{|c|c|c|}
\hline Social Capital & Knowledge & \\
\hline Social connectedness & Sharing Level & Anterifed \\
\hline Trust & \multirow{3}{*}{ Quantity } & \multirow{3}{*}{ Community loyalty } \\
\hline External & & \\
\hline Motivations & & \\
\hline Reciprocity & \multirow{2}{*}{ Quality } & \multirow{2}{*}{$\begin{array}{l}\text { Community } \\
\text { satisfaction }\end{array}$} \\
\hline Reputation & & \\
\hline
\end{tabular}

Figure I Theoretical model.

information could satisfy the individual needs to a great extent, to increase users' satisfaction with the community. ${ }^{45}$ Therefore, the following hypotheses are proposed:

H6a: Knowledge sharing quantity has a positive impact on community satisfaction.

H6b: Knowledge sharing quality has a positive impact on community satisfaction.

\section{The Mediating Role of Knowledge Sharing Level}

The generation and development of knowledge sharing are based on enterprise-user and user-user interactions in the virtual community. Interactive communication is the premise and guarantee of knowledge sharing. A relatively closed network with social capital and external motivation of the virtual community can create a psychological environment conducive to the promotion of user interaction and communication. On the other hand, knowledge is a complex and multidimensional construct, including flow properties that incorporate structured experience, unique expert ideas, and real insights and experiences from human beings. The knowledge and information obtained by community users through knowledge sharing may bring them a sense of pleasure and help them to make decisions, to improve the satisfaction and loyalty of community users to a certain extent. Therefore, the following hypotheses are proposed:

H7a: Knowledge sharing quantity plays a mediating role in the impact of social connectedness on community loyalty and satisfaction.

H7b: Knowledge sharing quality plays a mediating role in the impact of social connectedness on community loyalty and satisfaction.
H8a: Knowledge sharing quantity plays a mediating role in the impact of trust on community loyalty and satisfaction.

H8b: Knowledge sharing quality plays a mediating role in the impact of trust on community loyalty and satisfaction.

H9a: Knowledge sharing quantity plays a mediating role in the impact of reciprocity motivation on community loyalty and satisfaction.

H9b: Knowledge sharing quality plays a mediating role in the impact of reciprocity motivation on community loyalty and satisfaction.

H10a: Knowledge sharing quantity plays a mediating role in the impact of reputation motivation on community loyalty and satisfaction.

H10b: Knowledge sharing quality plays a mediating role in the impact of reputation motivation on community loyalty and satisfaction.

The theoretical model in this study is shown in Figure 1Figure 2.

\section{Methodology \\ Data Sources and Participants}

According to the 44th statistical report on the development of China's Internet issued by CNNIC, the 10-39year-old Internet users account for $65.1 \%$ of the total Internet users, of which the 20-29-year-old account for the highest proportion, reaching $24.6 \%$. And among the netizens in China, students are the most, accounting for $26.0 \%$. The theme of this study is a virtual community, and the respondents should be the groups with virtual community participation experience. As the main force of network participation, college students have a higher education level and strong stickiness to the network, so 


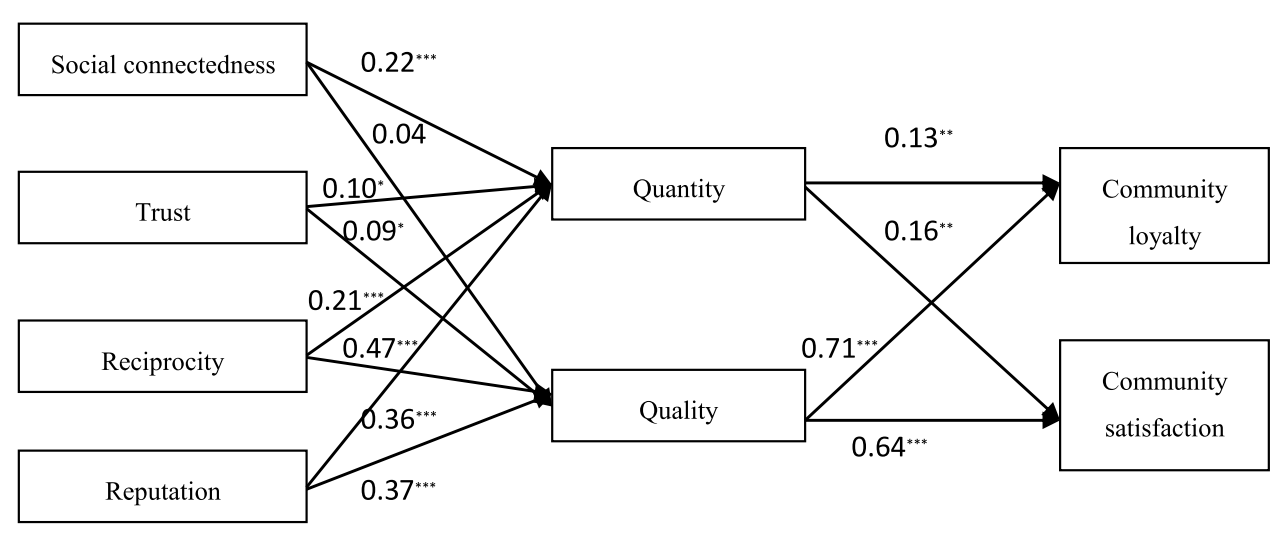

Figure 2 Structural model with results. Notes: ${ }^{*} p<0.05,{ }^{* *} p<0.01$, ***p $<0.001$.

this study chooses college students as the main survey objects.

The questionnaire is mainly aimed at the college students of Henan Province. The author, with the convenience of teachers' profession, gives questionnaires to the students in Henan University, Zhengzhou University, Henan University of Technology, and other universities. The teachers help them understand the problems in the e-commerce experimental course, guide them to answer them carefully. Besides, through the questionnaire distribution platform provided by the network company "questionnaire star", the electronic questionnaire is formed, and then people who have participated in the virtual community experience are selected in the circle of friends to forward the network link of the electronic questionnaire, and they are entrusted to select the appropriate subjects in their circle of friends to forward the questionnaire. The author gives them a serious account of the matters related to the questionnaire survey.

Finally, 533 valid questionnaires of the 600 collected responses were reserved through the careful inspection and elimination of the unqualified questionnaires (eg, questionnaires with obvious similarity and regularity), with a final valid response rate of $89 \%$.

Male and female respondents accounted for $46.5 \%$ and $53.5 \%$ respectively, while $51.4 \%$ were aged up to 20 years, $43.7 \%$ were $21-25$, and $4.9 \%$ were 26 and older. Participants had been members of the virtual communities of Bilibili.com, QQ Group, Baidu Tieba, iPhone Fan Club, Haier, HUAWEI, Arena of Valor, League of Legends, and others. The largest cohort (42.6\%) had been members for more than 3 years; $16.5 \%$ had been members for 2-3 years, $22.9 \%$ for $1-2$ years, and $18 \%$ for less than a year. The frequency of average weekly access of the virtual communities was divided into more than 12 times (41.3\%), 6-12 times (14.3\%), 3-6 times (23.4\%), and less than 3 times (21\%). The sample distribution is shown in Table 1.

\section{Measures}

All the variable scales were sourced from previous literature, modified according to the particular study context:

- Social capital, with two dimensions (social connectedness and trust), having four items each ( $\mathrm{Lu}$ and Yang, 2011; McLure et al, 2005). ${ }^{12,41}$

Table I Sample Distribution

\begin{tabular}{|c|c|c|c|}
\hline & Item & Frequency & Percent \\
\hline \multirow[t]{2}{*}{ Gender } & Male & 248 & 46.5 \\
\hline & Female & 285 & 53.5 \\
\hline \multirow[t]{5}{*}{ Age } & 20 and below & 274 & 51.4 \\
\hline & $21-25$ & 233 & 43.7 \\
\hline & $26-30$ & 14 & 2.6 \\
\hline & $31-40$ & 9 & 1.7 \\
\hline & 40 and above & 3 & 0.6 \\
\hline \multirow{4}{*}{$\begin{array}{l}\text { Duration of } \\
\text { registration }\end{array}$} & Less than I & 96 & 18.0 \\
\hline & $1-2$ & 122 & 22.9 \\
\hline & $2-3$ & 88 & 16.5 \\
\hline & More than 3 & 227 & 42.6 \\
\hline \multirow[t]{4}{*}{$\begin{array}{l}\text { Access } \\
\text { frequency }\end{array}$} & $\begin{array}{c}\text { Less than } 3 \text { times per } \\
\text { week }\end{array}$ & 112 & 21.0 \\
\hline & 3-6 times per week & 125 & 23.4 \\
\hline & 6-12 times per week & 76 & 14.3 \\
\hline & $\begin{array}{c}\text { More than } 12 \text { times } \\
\text { per week }\end{array}$ & 220 & 41.3 \\
\hline
\end{tabular}


- External motivation and other developed mature scales, with two dimensions (reputation motivation and reciprocity motivation), with three items each (Wiertz and de Ruyter, 2007). ${ }^{46}$

- Knowledge sharing, with two dimensions (quantity and quality), with four and five items (respectively) (Chang and Chuang, 2011; Lu and Yang, 2011). ${ }^{20,41}$

- Community loyalty, with four items (Chieh-Peng and Ding, 2005). ${ }^{47}$

- Community satisfaction, with four items (Negash et al, 2003). ${ }^{48}$

The setting of variable measurement items and the confirmatory factor analysis data are shown in Table 2.

\section{Empirical Results and Analysis Reliability and Validity}

Reliability refers to the consistency of repeat measurements on the same object by the same method. It is commonly measured with Cronbach's alpha coefficient. Generally, the higher the value of reliability, the better the quality of the questionnaire design. As shown in Table 2, the Cronbach's alpha of all study variables exceeded 0.8, indicating high consistency and reliability.

The construct validity, convergent validity, and discriminant validity were tested by confirmatory factor analysis. Construct validity was mainly based on the absolute fit index and incremental fit index of the structural equation, with the fit index of the model as $\mathrm{X} 2 / \mathrm{df}=2.902<3$, as well as RMSEA $=0.060<0.08, \mathrm{SRMR}=0.0612<0.08, \mathrm{IFI}=0.924$, $\mathrm{CFI}=0.924$, and TLI $=0.915$, which were all acceptable by exceeding 0.9, thus proving the better goodness-of-fit of the measurement model. Convergent validity means the aggregation of items measuring the same latent trait on the same facet of the latent variable, with a high correlation between the measured values among items. The criteria for convergent validity include: (i) all factor loads should be greater than 0.5 ; (ii) the composite reliability (CR) of each variable should be greater than 0.7; (iii) and the average variance extracted (AVE) should be greater than $0.5 .^{49,50}$

As shown in Table 2, factor loads of all measurement items exceeded 0.5, and the CR and AVE of each variable respectively exceeded 0.8 and 0.5 , proving the good convergent validity of the measurement scale. Discriminant validity refers to the low correlation or significant difference between the latent traits represented by each latent variable and those represented by other latent variables, with the criterion that the square root of AVE of each latent variable should be greater than its correlation coefficient with other latent variables. As shown in Table 3, the square root of the AVE of each variable is greater than its correlation coefficient with other latent variables, proving the acceptable discriminant validity of the measurement model.

\section{Structural Equation Model Test}

To test the study hypotheses, AMOS22.0 software was used in this study to further analyze the structural equation model. The analysis results of paths between latent variables were shown in Table 4, in summary, except for the unsupported H1b, hypotheses H1a, H2a, H2b, H3a, H3b, H4a, H4b, H5a, H5b, H6a, and H6b were all supported, as described below:

- Social connectedness had a significant positive impact on knowledge sharing quantity ( $\beta=0.222$ and $\mathrm{p}<0.001$ ), thus hypothesis H1a held.

- Social connectedness did not have a significant positive impact on knowledge sharing quality ( $\beta=0.036$ and $\mathrm{p}>0.05$ ), thus hypothesis H1b did not hold.

- Trust had a significant positive impact on knowledge sharing quantity $(\beta=0.098$ and $p<0.05)$, thus $\mathrm{H} 2 \mathrm{a}$ held.

- Trust had a significant positive impact on knowledge sharing quality $(\beta=0.091$ and $\mathrm{p}<0.05$ ), thus $\mathrm{H} 2 \mathrm{~b}$ held.

- Reciprocity motivation had a significant positive impact on knowledge sharing quantity ( $\beta=0.214$ and $\mathrm{p}<0.001$ ), thus H3a held.

- Reciprocity motivation had a significant positive impact on knowledge sharing quality $(\beta=0.466$ and $\mathrm{p}<0.001$ ), thus $\mathrm{H} 3 \mathrm{~b}$ held.

- Reputation motivation had a significant positive impact on knowledge sharing quantity $(\beta=0.362$ and $\mathrm{p}<0.001$ ), thus H4a held.

- Reputation motivation had a significant positive impact on knowledge sharing quality $(\beta=0.367$ and $\mathrm{p}<0.001$ ), thus $\mathrm{H} 4 \mathrm{~b}$ held.

- Knowledge sharing quantity had a significant positive impact on community loyalty $(\beta=0.128$ and $\mathrm{p}<0.01$ ), thus H5a held.

- Knowledge sharing quality had a significant positive impact on community loyalty $(\beta=0.707$ and $\mathrm{p}<0.001$ ), thus H5b held. 
Table 2 Setting of Variable Measurement Item and Analysis on Confirmatory Factors

\begin{tabular}{|c|c|c|c|c|}
\hline Variables & Items & $\begin{array}{l}\text { Factor } \\
\text { Loading }\end{array}$ & AVE & CR \\
\hline \multirow{4}{*}{$\begin{array}{l}\text { Social } \\
\text { connectedness } \\
\text { Cronbach 's } \\
\text { alpha }=0.904\end{array}$} & I have a close interaction with other members of this community & 0.829 & \multirow[t]{4}{*}{0.7065} & \multirow[t]{4}{*}{0.9058} \\
\hline & I spend a lot of time in interactions with other members of this community & 0.829 & & \\
\hline & I know a lot of members in this community & 0.811 & & \\
\hline & I communicate frequently with other members of this community & 0.891 & & \\
\hline \multirow{4}{*}{$\begin{array}{l}\text { Trust } \\
\text { Cronbach 's } \\
\text { alpha }=0.872\end{array}$} & Members of this community do not take advantages of others & 0.609 & \multirow[t]{4}{*}{0.6220} & \multirow[t]{4}{*}{$0.866 \mathrm{I}$} \\
\hline & Members of this community always keep their promises to other members & 0.845 & & \\
\hline & Members of this community do not deliberately disrupt the conversation & 0.793 & & \\
\hline & Members of this community treat others honestly & 0.880 & & \\
\hline \multirow{3}{*}{$\begin{array}{l}\text { Reciprocity } \\
\text { motivation } \\
\text { Cronbach 's } \\
\text { alpha }=0.848\end{array}$} & $\begin{array}{l}\text { I am willing to provide help and share my information when other members of this } \\
\text { community need help. }\end{array}$ & 0.782 & \multirow[t]{3}{*}{0.6538} & \multirow[t]{3}{*}{0.8496} \\
\hline & I think other members of this community will help me with my request. & 0.770 & & \\
\hline & $\begin{array}{l}\text { After getting help in the community, I feel I should give back and help other members of } \\
\text { this community }\end{array}$ & 0.870 & & \\
\hline \multirow{3}{*}{$\begin{array}{l}\text { Reputation } \\
\text { motivation } \\
\text { Cronbach 's } \\
\text { alpha }=0.884\end{array}$} & Sharing my knowledge and experience can improve my visibility in the community & 0.829 & \multirow[t]{3}{*}{0.716} & \multirow[t]{3}{*}{0.8833} \\
\hline & Sharing my knowledge and experience can improve my status in the community & 0.895 & & \\
\hline & Sharing my knowledge and experience can win the respect and recognition from others & 0.813 & & \\
\hline \multirow{4}{*}{$\begin{array}{l}\text { Knowledge sharing } \\
\text { quantity } \\
\text { Cronbach 's } \\
\text { alpha }=0.855\end{array}$} & I always share my knowledge and experience in the community & 0.726 & \multirow[t]{4}{*}{0.6031} & \multirow[t]{4}{*}{0.8579} \\
\hline & I will actively participate in the discussion and put forward my ideas. & 0.834 & & \\
\hline & I will actively answer questions from other members of the community & 0.839 & & \\
\hline & $\begin{array}{l}\text { I will recommend the knowledge, information and experience learned from other places } \\
\text { to other members of the community }\end{array}$ & 0.697 & & \\
\hline \multirow{5}{*}{$\begin{array}{l}\text { Knowledge sharing } \\
\text { quality } \\
\text { Cronbach 's } \\
\text { alpha }=0.859\end{array}$} & The knowledge I share in the community is relevant to the topic & 0.705 & \multirow[t]{5}{*}{0.5276} & \multirow[t]{5}{*}{0.8476} \\
\hline & The knowledge I share in this community is easy to understand & 0.773 & & \\
\hline & The knowledge I share in this community is reliable & 0.789 & & \\
\hline & The knowledge I share in this community is complete & 0.673 & & \\
\hline & The knowledge I share in the community is based on close inspection & 0.684 & & \\
\hline \multirow{4}{*}{$\begin{array}{l}\text { Community loyalty } \\
\text { Cronbach 's } \\
\text { alpha }=0.831\end{array}$} & I will continue to participate in the activities held by this community & 0.777 & \multirow[t]{4}{*}{0.5715} & \multirow[t]{4}{*}{0.8400} \\
\hline & I intend to continue to be a member of this community in the future & 0.842 & & \\
\hline & I will continue to the close cooperation with other members of the community & 0.790 & & \\
\hline & I will encourage my family and friends to join the community & 0.591 & & \\
\hline \multirow{4}{*}{$\begin{array}{l}\text { Community } \\
\text { satisfaction } \\
\text { Cronbach 's } \\
\text { alpha }=0.882\end{array}$} & I think it is a funny community & 0.818 & \multirow[t]{4}{*}{0.6500} & \multirow[t]{4}{*}{0.8813} \\
\hline & I enjoy the activities in this community & 0.803 & & \\
\hline & I am very satisfied with the services and activities provided by the community & 0.776 & & \\
\hline & I am very happy to join the community & 0.827 & & \\
\hline
\end{tabular}

Notes: Data from refernces $12,41,46,47,48$. 
Table 3 Confirmatory Factor Analysis, Discriminant Validity, and Correlation Coefficient Results

\begin{tabular}{|c|c|c|c|c|c|c|c|c|}
\hline & SIT & TR & RE & RM & KS & KSB & COL & $\cos$ \\
\hline SIT & $0.84 I$ & & & & & & & \\
\hline $\mathrm{TR}$ & $0.308 * *$ & 0.789 & & & & & & \\
\hline RE & $0.219 * *$ & $0.350 * *$ & 0.809 & & & & & \\
\hline RM & $0.192 * *$ & $0.215^{* *}$ & $0.514 * *$ & 0.846 & & & & \\
\hline KS & $0.369 * *$ & $0.27 I^{* *}$ & $0.418 * *$ & $0.48 I^{* *}$ & 0.777 & & & \\
\hline KSB & $0.222 * *$ & $0.330 * *$ & $0.563 * *$ & $0.539 * *$ & $0.603 * *$ & 0.726 & & \\
\hline $\mathrm{COL}$ & $0.352 * *$ & $0.292 * *$ & $0.524 * *$ & $0.479 * *$ & $0.485^{* *}$ & $0.593^{* *}$ & 0.756 & \\
\hline $\cos$ & $0.221^{* *}$ & $0.300 * *$ & $0.517 * *$ & $0.464 * *$ & $0.48 I^{* *}$ & $0.577^{* *}$ & $0.707^{* *}$ & 0.806 \\
\hline
\end{tabular}

Note: **Represents the significant correlation in diagonal is the square root of AVE value at the level of 0.01 (both sides).

Table 4 Analysis on Path Coefficients of Structural Equation Model

\begin{tabular}{|l|l|l|l|l|l|}
\hline Relationship Between Variables & $\begin{array}{l}\text { Standardized Path } \\
\text { Coefficients }\end{array}$ & S.E & C.R & P value & $\begin{array}{l}\text { Significant } \\
\text { Level }\end{array}$ \\
\hline Social connectedness $\longrightarrow$ Knowledge sharing quantity & 0.222 & 0.025 & 5.030 & $* * *$ & Significant \\
Trust $\rightarrow$ Knowledge sharing quantity & 0.098 & 0.030 & 2.156 & 0.031 & Significant \\
Reciprocity motivation $\rightarrow$ Knowledge sharing quantity & 0.214 & 0.056 & 3.372 & $* * *$ & Significant \\
Reputation motivation $\longrightarrow$ Knowledge sharing quantity & 0.362 & 0.053 & 6.012 & $* * *$ & Significant \\
Social connectedness $\longrightarrow$ Knowledge sharing quality & 0.036 & 0.019 & 0.970 & 0.332 & Insignificant \\
Trust $\rightarrow$ Knowledge sharing quality & 0.091 & 0.024 & 2.317 & 0.020 & Significant \\
Reciprocity motivation $\rightarrow$ Knowledge sharing quality & 0.466 & 0.047 & 7.890 & $* * *$ & Significant \\
Reputation motivation $\rightarrow$ Knowledge sharing quality & 0.367 & 0.042 & 6.984 & $* * *$ & Significant \\
Knowledge sharing quantity $\rightarrow$ Community loyalty & 0.128 & 0.062 & 2.324 & $* *$ & Significant \\
Knowledge sharing quantity $\rightarrow$ Community satisfaction & 0.155 & 0.061 & 2.773 & $* *$ & Significant \\
Knowledge sharing quality $\rightarrow$ Community loyalty & 0.707 & 0.081 & 10.793 & $* * *$ & Significant \\
Knowledge sharing quality $\rightarrow$ Community satisfaction & 0.643 & 0.079 & 9.890 & $* * *$ & Significant \\
\hline
\end{tabular}

Notes: $* * * p<0.001 * * p<0.01$ C.R. value is $Z$ value.

- Knowledge sharing quantity had a significant positive impact on community satisfaction $(\beta=0.155$ and $\mathrm{p}<0.01$ ), thus H6a held.

- Knowledge sharing quality had a significant positive impact on community satisfaction $(\beta=0.643$ and $\mathrm{p}<0.001$ ), thus H6b held.

\section{Mediating Effect Test}

The process plug-in unit of SPSS22.0 was used in this study to test the mediating effect by the Bootstrap method. The sample size was set to 5000, based on the methods proposed by Zhao et al, with the nonparametric percentile method for deviation correction used for sampling, and the confidence degree of confidence intervals set to $95 \%{ }^{51}$ The upper and lower limits of the indirect effect in this confidence interval not containing zero indicate the existence of a mediating effect. The path analysis on the structural equation model indicates that the impact of social connectedness on the knowledge sharing quality of virtual communities was not supported, so there was no need to test the mediating effect of this path.

Under the control of gender and age, the Model (Model 4 is the simple mediating model) in SPSS Macro programmed by Hayes was used to test the mediating role of the knowledge sharing level of virtual communities on the impact of social capital and external motivation on community loyalty and satisfaction. ${ }^{52}$ The results are shown in Table 5; except for the unsupported $\mathrm{H} 7 \mathrm{~b}$, the hypotheses $\mathrm{H} 7 \mathrm{a}, \mathrm{H} 8 \mathrm{a}, \mathrm{H} 8 \mathrm{~b}$, H9a, H9b, H10a, and H11b hold, as described below:

Knowledge sharing quantity had a significant mediating effect, indicated by the respective indirect effects, between community loyalty and: social connectedness $(0.0983)$, trust $(0.0875)$, reciprocity motivation (0.1366), and reputation motivation $(0.1537)$.

Knowledge sharing quantity had a significant mediating effect, indicated by the respective indirect effects, between community satisfaction and: social connectedness (0.1138), trust $(0.0891)$, reciprocity $(0.1410)$, and reputation $(0.1620)$. 
Table 5 Bootstrap Analysis of Mediating Effect Test

\begin{tabular}{|c|c|c|c|c|c|c|}
\hline \multirow[t]{3}{*}{ Mediating Effect } & \multicolumn{3}{|c|}{$\begin{array}{l}\text { Social Connectedness } \rightarrow \text { Knowledge Sharing } \\
\text { Level } \rightarrow \text { Community Loyalty }\end{array}$} & \multicolumn{3}{|c|}{$\begin{array}{l}\text { Social Connectedness } \rightarrow \text { Knowledge Sharing } \\
\text { Level } \rightarrow \text { Community Satisfaction }\end{array}$} \\
\hline & \multirow[t]{2}{*}{ Effect Value } & \multicolumn{2}{|c|}{ 95\% Confidence Interval } & \multirow[t]{2}{*}{ Effect value } & \multicolumn{2}{|c|}{ 95\% Confidence Interval } \\
\hline & & Lower Limit & Upper Limit & & Lower Limit & Upper Limit \\
\hline Knowledge sharing quantity & 0.0983 & 0.0677 & 0.1311 & 0.1138 & 0.0806 & 0.1492 \\
\hline \multirow[t]{3}{*}{ Mediating effect } & \multicolumn{3}{|c|}{$\begin{array}{l}\text { Trust } \rightarrow \text { Knowledge sharing level } \rightarrow \text { Community } \\
\text { loyalty }\end{array}$} & \multicolumn{3}{|c|}{$\begin{array}{l}\text { Trust } \rightarrow \text { Knowledge sharing level } \rightarrow \text { Community } \\
\text { satisfaction }\end{array}$} \\
\hline & \multirow[t]{2}{*}{ Effect value } & \multicolumn{2}{|c|}{$95 \%$ confidence interval } & \multirow[t]{2}{*}{ Effect value } & \multicolumn{2}{|c|}{$95 \%$ confidence interval } \\
\hline & & Lower limit & Upper limit & & Lower limit & Upper limit \\
\hline Knowledge sharing quantity & 0.0875 & 0.0545 & 0.1246 & 0.0891 & 0.0563 & 0.1256 \\
\hline Knowledge sharing quality & 0.1299 & 0.0909 & 0.1707 & 0.1288 & 0.0869 & 0.1727 \\
\hline \multirow[t]{3}{*}{ Mediating effect } & \multicolumn{3}{|c|}{$\begin{array}{l}\text { Reciprocity } \rightarrow \text { Knowledge sharing level } \\
\rightarrow \text { Community Loyalty }\end{array}$} & \multicolumn{3}{|c|}{$\begin{array}{l}\text { Reciprocity } \rightarrow \text { Knowledge sharing level } \\
\rightarrow \text { Community satisfaction }\end{array}$} \\
\hline & \multirow[t]{2}{*}{ Effect value } & \multicolumn{2}{|c|}{$95 \%$ confidence interval } & \multirow[t]{2}{*}{ Effect value } & \multicolumn{2}{|c|}{$95 \%$ confidence interval } \\
\hline & & Lower limit & Upper limit & & Lower limit & Upper limit \\
\hline Knowledge sharing quantity & 0.1366 & 0.0938 & 0.1881 & 0.1410 & 0.0990 & 0.1877 \\
\hline Knowledge sharing quality & 0.2388 & 0.1854 & 0.2952 & 0.2362 & 0.1824 & 0.2933 \\
\hline \multirow[t]{3}{*}{ Mediating effect } & \multicolumn{3}{|c|}{$\begin{array}{l}\text { Reputation } \rightarrow \text { Knowledge sharing level } \\
\rightarrow \text { Community Loyalty }\end{array}$} & \multicolumn{3}{|c|}{$\begin{array}{l}\text { Reputation } \rightarrow \text { Knowledge sharing level } \\
\rightarrow \text { Community satisfaction }\end{array}$} \\
\hline & \multirow[t]{2}{*}{ Effect value } & \multicolumn{2}{|c|}{ 95\% confidence interval } & \multirow[t]{2}{*}{ Effect value } & \multicolumn{2}{|c|}{$95 \%$ confidence interval } \\
\hline & & Lower limit & Upper limit & & Lower limit & Upper limit \\
\hline Knowledge sharing quantity & 0.1537 & 0.1066 & 0.2034 & 0.1620 & 0.1152 & 0.2141 \\
\hline Knowledge sharing quality & 0.2383 & 0.1807 & 0.3014 & 0.2407 & 0.1852 & 0.3013 \\
\hline
\end{tabular}

Knowledge sharing quality had a significant mediating effect, indicated by the respective indirect effects, between community loyalty and: trust (0.1299), reciprocity (0.2388), and reputation (0.2383).

Knowledge sharing quality had a significant mediating effect, indicated by the respective indirect effects, between community satisfaction and: trust $(0.1288)$, reciprocity (0.2362), and reputation (0.2407).

\section{Discussion and Conclusion}

\section{Main Findings}

Based on the social capital theory and social exchange theory, this paper constructed the influence model of virtual community knowledge sharing on community satisfaction and community loyalty. The results indicated three main findings.
First, trust, reputation motivation, and reciprocity motivation positively affect both the quantity and quality of knowledge sharing. The higher the degree of trust of community members, the higher the degree of the pursuit of their status and reputation in the community, and the stronger their sense of reciprocity, the higher the frequency of knowledge sharing in the community, and the more attention they pay to the integrity, accuracy, and professionalism of the knowledge shared. Chang and Chuang, Lee and Hyun, Kumi and Sabherwal also verified that trust and reputation motivation could promote knowledge sharing among users in virtual communities. $^{6,20,53}$ Social connectedness had a positive impact on the quantity of knowledge sharing, but it had no significant impact on the quality of knowledge sharing. Community members tended to express their views and knowledge in the process of interaction, but they did not 
pay special attention to the accuracy and professionalism of their views and knowledge.

Second, knowledge sharing in virtual communities has a positive impact on community satisfaction and community loyalty. The greater the number of users sharing knowledge in the virtual community, the higher the quality of shared knowledge, and the higher the satisfaction and loyalty of users. Lin et al verified the impact of knowledge sharing on community loyalty, but only examined the amount of knowledge sharing when measuring knowledge sharing. ${ }^{9}$ From the study, we found that when users participate in the virtual community, they not only care about whether they can find knowledge in the virtual community, but also pay attention to the accuracy, professionalism, and integrity of the acquired knowledge. When users can obtain a lot of valuable knowledge in line with their own needs in the virtual community, they will recognize the value of the community, feel satisfied with it, and become loyal users. ${ }^{54}$

Thirdly, knowledge sharing quantity had a mediating effect between social connectedness and trust, reciprocity, reputation, community loyalty, and community satisfaction; and knowledge sharing quality had a mediating effect between trust, reciprocity, reputation, community loyalty, and community satisfaction. Trust, reciprocal motivation and reputation motivation had a significant impact on community loyalty and community satisfaction through the quantity and quality of knowledge sharing, while social connectedness had a significant impact on community loyalty and community satisfaction only through the quantity of knowledge sharing. In virtual communities, users often participate in discussions based on hobbies, to help each other, strengthen connections with others, gain trust, improve their reputation, and other motivations to participate in discussions and share their knowledge. It is this continuous knowledge creation that increases the stickiness of the community. And then produce community satisfaction and community loyalty to the community. ${ }^{55}$

\section{Research Contribution}

\section{Theoretical Significance}

Firstly, this paper constructs and validates the research model of influencing factors of consumer knowledge sharing in virtual communities, which enriches the theoretical system of knowledge sharing research in virtual communities. This paper studies the knowledge sharing of virtual communities from the two perspectives of the quantity of knowledge sharing and the quality of knowledge sharing and confirms that the variables under social capital (social connectedness, trust) and external motivations (reputation motivation, reciprocity motivation) will have an impact on the quantity and quality of knowledge sharing. Many previous studies measured knowledge sharing as a whole variable, ${ }^{8,9}$ or divided knowledge in the study of knowledge sharing into explicit knowledge and tacit knowledge. However, the decision-making of consumers and enterprises often requires the support of high-quality knowledge, which brings a sense of value and satisfaction. ${ }^{55}$

Secondly, the article takes the knowledge sharing of users in virtual communities to cultivate loyal users and improve user satisfaction, enriching the research theory of consumer loyalty and satisfaction. This paper confirms that the quantity and quality of knowledge sharing have a significant positive impact on the satisfaction and loyalty of virtual community users. Previous studies on the aftereffects of knowledge sharing in virtual communities focused on the influence of knowledge sharing on corporate innovation, brand attitudes, brand identity, etc. ${ }^{56-60}$ In cultivating loyal consumers, scholars mostly investigated consumer loyalty in the traditional organizational environment. Few scholars extended traditional consumer loyalty to virtual communities. The survival and development of a virtual community require a large number of active users. Low user activity will make the value of the virtual community to the enterprise disappear, and a high rate of user churn will make the virtual community unable to survive. This research provides a new idea for enterprises and virtual community managers to improve user loyalty.

\section{Implications for Practice}

First, this paper studies knowledge sharing in virtual communities from the perspectives of quantity and quality of knowledge sharing and proves that variables under social capital (social connectedness and trust) and external motivation (reputation motivation and reciprocity motivation) have an impact on the quantity and quality of knowledge sharing. Furthermore, it demonstrates that the quantity and quality of knowledge sharing have significant positive impacts on community satisfaction and community loyalty. These insights enrich theoretical research on knowledge-sharing behavior in virtual communities. As far as knowledge sharing in virtual communities is concerned, some users may prefer to share knowledge frequently, but not consider the integrity and professionalism of the shared knowledge, while other users pay more attention to the accuracy, integrity, and professionalism of the shared knowledge when sharing knowledge. 
However, there may be differences in the influencing factors of the two behaviors, so it is necessary to study sharing quality from two perspectives. Besides, companies can also attract consumers to participate in discussions, exchange experiences, and enhance feelings between community consumers through grasping the connection between hot topics and community products and services.

Secondly, enterprises should emphasize the relationship between community loyalty, community satisfaction, and knowledge sharing level. Community users should be encouraged by managers to express more ideas and share more valuable knowledge. The achievement of a larger possibility for users to gain the knowledge and information they need based on the increasingly accurate knowledge they share among themselves can enhance their loyalty and satisfaction to communities. The satisfaction and loyalty of community users is the most important factor for healthy enterprise development and user retention and enhancement, which are vital to the long-term management of community platforms. The virtual community can increase the contact frequency of friends in reality by holding various online and offline activities, and the higher the frequency of their information exchange, the user is likely to have a sense of belonging to the virtual community and increase satisfaction in the harvesting of friendship and knowledge. ${ }^{61,62}$ Besides, through comments and feedback from users of virtual communities, companies can quickly understand their problems and improve their qualities, thereby strengthen users' loyalty to the virtual communities.

\section{Research Limitations and Future Directions}

The shortcomings of this study include the difficulty of accurately judging the relationships between variables from the dynamic perspective concerning the crosssection data used in this study (unlike the data obtained from the longitudinal-time research method). There is a lack of universality in the selection of college students as the main source for samples, thus the enhancement of sample diversity in subsequent studies can improve the generalizability of statistical findings.

\section{Data Sharing Statement}

The datasets generated during and/or analyzed during the current study are available from the corresponding author on reasonable request.

\section{Compliance with Ethical Standards}

Ethical Approval: This study was reviewed and approved by Ethics Committee of Henan University in China. We declare that participants in our research study allow us to use their data for academic research and publication. All the participants were anonymous and their data was protected. All participants provided informed consent and this study was conducted in accordance with the Declaration of Helsinki.

\section{Informed Consent}

The corresponding author is sure that informed, written consent was obtained from all participants and was clearly stated. Written informed consent to participate was obtained from the parents/ guardians of the minors included in this study.

\section{Funding}

The research is supported by Major Program of basic research of philosophy and social sciences in colleges and universities of henan province (No. 2021-JCZD-02), and Cultivation Program for Innovative Team of Philosophy and Social Sciences of Henan University (No.2019CXTD008), and Social Science planning project of Henan Province (No.2019BJJ017), and Program for Science and Technology Innovation Talents at the Universities of Henan Province (No. 2019-cx-012), and Important Project for Educational Science Planning of Henan Province (No. [2020]-JKGHZD-11), The start-up funding for Ph.D. scientific research of Huaibei Normal University of China(No. 03106098).

\section{Disclosure}

The authors declare no conflicts of interest in this work.

\section{References}

1. Belk R. Extended self and the digital world. Curr Opin Psychol. 2016;10:50-54. doi:10.1016/j.copsyc.2015.11.003

2. Widayat W. Assessing the motives and gratification of virtual community. J Innov Econ. 2019;3(2):111-127. doi:10.22219/jibe. v3i02.10056

3. Brodie RJ, Ilic A, Juric B, et al. Consumer engagement in a virtual brand community: an exploratory analysis. J Bus Res. 2013;66 (1):105-114. doi:10.1016/j.jbusres.2011.07.029

4. Al-Emran M, Teo T. Do knowledge acquisition and knowledge sharing really affect e-learning adoption? An Empirical Study. Educ Inf Technol. 2020;25(3):1983-1998. doi:10.1007/s10639-019-10062-w

5. Gloor P, Fronzetti Colladon A, Giacomelli G, et al. The impact of virtual mirroring on customer satisfaction. J Bus Res. 2017;75:67-76. doi:10.1016/j.jbusres.2017.02.010 
6. Kumi R, Sabherwal R. Knowledge sharing behavior in online discussion communities: examining behavior motivation from social and individual perspectives. Knowl Process Manag. 2019;26(2):110-122. doi:10.1002/kpm. 1574

7. Wasko MML, Faraj S. Why should I share? Examining social capital and knowledge contribution in electronic networks of practice. MIS Q. 2005;29(1):35-57. doi:10.2307/25148667

8. Choi G, Nam C, Kim S, et al. Where does knowledge-sharing motivation come from? The case of third-party developer in mobile platforms. J Knowl Manag. 2020;24(7):1681-1704. doi:10.1108/ JKM-08-2019-0449

9. Lin M, Hung SW, Chen CJ. Fostering the determinants of knowledge sharing in professional virtual communities. Comput Human Behav. 2009;25(4):929-939. doi:10.1016/j.chb.2009.03.008

10. Fauzi MA. Knowledge sharing in Asia Pacific via virtual community platform: a systematic review. Int $J$ Web Based Communities. 2019;15(4):368-394. doi:10.1504/IJWBC.2019.10023490

11. Autio E, Dahlander L, Frederiksen L. Information exposure, opportunity evaluation, and entrepreneurial action: an investigation of an online user community. Acad Manag J. 2013;56(5):1348-1371. doi:10.5465/amj.2010.0328

12. McLure W, Faraj M. Why should i share? Examining social capital and knowledge contribution in electronic networks of practice. MIS Q. 2005;29(1):35-57. doi:10.5555/2017245.2017249

13. Ridings CM, Gefen D, Arinze B. Some antecedents and effects of trust in virtual communities. J Strateg Inf Syst. 2002;11(3/4):271. doi:10.1016/S0963-8687(02)00021-5

14. Cai Y, Shi W. The influence of the community climate on users' knowledge-sharing intention: the social cognitive theory perspective. Behav Inf Technol. 2020;2020:1-17. doi:10.1080/0144929X.20 20.1808704

15. van den Hooff B, de Ridder Jan A. Knowledge sharing in context: the influence of organizational commitment, communication climate and CMC use on knowledge sharing. J Knowl Manag. 2004;8 (6):117-130. doi:10.1108/13673270410567675

16. Hau YS, Kim Y. Why would online gamers share their innovation-conducive knowledge in the online game user community? Integrating individual motivations and social capital perspectives. Comput Human Behav. 2011;27(2):956-970. doi:10.1016/j.chb.2010.11.022

17. Kim W, Park J. Examining structural relationships between work engagement, organizational procedural justice, knowledge sharing, and innovative work behavior for sustainable organizations. Sustainability. 2017;9(2):205. doi:10.3390/su9020205

18. Zheng TT. A literature review on knowledge sharing. Open J Soc Sci. 2017;5(1):51-58. doi:10.4236/jss.2017.53006

19. Nahapiet J, Ghoshal S. Social capital, intellectual capital, and the organizational advantage. Acad Manag Rev. 1998;23(2):242-266. doi:10.5465/amr.1998.533225

20. Chang $\mathrm{HH}$, Chuang SS. Social capital and individual motivations on knowledge sharing: participant involvement as a moderator. Inf Manag. 2011;48(1):9-18. doi:10.1016/j.im.2010.11.001

21. Kwon SW, Adler PS. Social capital: maturation of a field of research. Acad Manag Rev. 2014;39(4):412-422. doi:10.5465/amr.2014.0210

22. Fisher G. Online communities and firm advantages. Acad Manag Rev. 2019;44(2):279-298. doi:10.5465/amr.2015.0290

23. Feng Y, Ye H. Why do you return the favor in online knowledge communities? A study of the motivations of reciprocity. Comput Human Behav. 2016;63:342-349. doi:10.1016/j.chb.2016.05.007

24. Hsu CL, Lin JCC. Acceptance of blog usage: the roles of technology acceptance, social influence and knowledge sharing motivation. Inf Manag. 2008;45(1):65-74. doi:10.1016/j.im.2007.11.001

25. Wang J, Liu L. Study on the mechanism of customers' participation in knowledge sharing. Expert Syst. 2019;36(5):e12367. doi:10.1111/ exsy. 12367
26. López Sánchez JÁ, Santos Vijande ML, Trespalacios Gutiérrez JA. The effects of manufacturer's organizational learning on distributor satisfaction and loyalty in industrial markets. Ind Mark Manag. 2011;40(4):624-635. doi:10.1016/j.indmarman.2010.12.003

27. Ryu S, Suh A. Online service or virtual community? Building platform loyalty in reward-based crowd funding. Internet Res. 2020;31 (1):315-340. (early access). doi:10.1108/INTR-06-2019-0256

28. Koh J, Kim YG. Knowledge sharing in virtual communities: an e-business perspective. Expert Syst Appl. 2004;26(2):155-166. doi:10.1016/S0957-4174(03)00116-7

29. Cardozo RN. An experimental study of customer effort, expectation, and satisfaction. J Market Res. 1965;2(3):244-249. doi:10.2307/ 3150182

30. Ratnasari RT, Gunawan S, Septiarini DF, et al. Customer satisfaction between perceptions of environment destination brand and behavioral intention. Int J Innov Creativity Chang. 2020;10(12):472-487.

31. Kotler P, Keller KL. Marketing Management. 13th ed. Upper Saddle River: Pearson Prentice Hall; 2009.

32. Oliver RL, Rust RT, Varki S. Customer delight: foundations, findings, and managerial insight. $J$ Retail. 1997;73(3):311. doi:10.1016/S00224359(97)90021-X

33. Michna A. The mediating role of firm innovativeness in the relationship between knowledge sharing and customer satisfaction in SMEs. Eng Econ. 2018;29(1):93-103. doi:10.5755/j01.ee.29.1.19027

34. Tsai W, Ghoshal S. Social capital and value creation: the role of intrafirm networks. Acad Manag J. 1998;41(4):464-476. doi: $10.2307 / 257085$

35. Chiu CM, Hsu MH, Wang ETG. Understanding knowledge sharing in virtual communities: an integration of social capital and social cognitive theories. Decis Support Syst. 2006;42(3):1872-1888. doi:10.1016/j.dss.2006.04.001

36. Chow WS, Lai SC. Social network, social trust and shared goals in organizational knowledge sharing. Inf Manag. 2008;45(7):458-465. doi:10.1016/j.im.2008.06.007

37. Blau P.M. Potlach, Power, and Social Structure. (Book Reviews: Exchange and Power in Social Life). Science. 1965. doi:10.1126/ science.147.3654.137

38. Zhang X, Liu S, Deng Z, et al. Knowledge sharing motivations in online health communities: a comparative study of health professionals and normal users. Comput Human Behav. 2017;75:797-810. doi:10.1016/j.chb.2017.06.028

39. Rode H. To share or not to share: the effects of extrinsic and intrinsic motivations on knowledge-sharing in enterprise social media platforms. J Inf Technol. 2016;31(2):152-165. doi:10.1057/ jit.2016.8

40. Wang Y, Fesenmaier DR. Towards understanding members' general participation in and active contribution to an online travel community. Tour Manag. 2004;25(6):709-722. doi:10.1016/j.tourman.20 03.09.011

41. Lu Y, Yang D. Information exchange in virtual communities under extreme disaster conditions. Decis Support Syst. 2011;50(2):529-538. doi:10.1016/j.dss.2010.11.011

42. Yao CY, Tsai CC, Fang YC. Understanding social capital, team learning, members' e-loyalty and knowledge sharing in virtual communities. Total Qual Manag Bus Excell. 2015;26(5-6):619-631. doi:10.1080/14783363.2013.865918

43. Cheng FF, Wu CS, Chen YC. Creating customer loyalty in online brand communities. Comput Human Behav. 2020;107:105752. doi:10.1016/j.chb.2018.10.018

44. Rubera G, Kirca A. You gotta serve somebody: the effects of firm innovation on customer satisfaction and firm value. J Acad Mark Sci. 2017;45(5):741-761. doi:10.1007/s11747-016-0512-7

45. Lin H, Fan W, Wallace L, et al. An empirical study of web-based knowledge community success. 40th Annual Hawaii International Conference on System Sciences; 2007:178. 
46. Wiertz C, de Ruyter K. Beyond the call of duty: why customers contribute to firm-hosted commercial online communities. Organ Stud. 2007;28(3):347-376. doi:10.1177/0170840607076003

47. Chieh-Peng L, Ding CG. Opening the black box: assessing the mediating mechanism of relationship quality and the moderating effects of prior experience in ISP service. Int J Serv Ind Manag. 2005;16(1):55-80. doi:10.1108/09564230510587159

48. Negash S, Ryan T, Igbaria M. Quality and effectiveness in web-based customer support systems. Inf Manag. 2003;40(8):757-768. doi:10.1016/S0378-7206(02)00101-5

49. Chen A, Karahanna E. Life interrupted: the effects of technology-mediated work interruptions on work and nonwork outcomes. MIS Q. 2018;42(4):1023-1042. doi:10.25300/MISQ/ 2018/13631

50. Segars AH. Assessing the unidimensionality of measurement: a paradigm and illustration within the context of information systems research. Omega. 1997;25(1):107-121. doi:10.1016/S0305-0483(96) 00051-5

51. Zhao X, Lynch JG Jr, Chen Q. Reconsidering Baron and Kenny: myths and truths about mediation analysis. J Consum Res. 2010;37 (2):197-206. doi:10.1086/651257

52. Hayes AF. Process: a versatile computational tool for observed variable mediation, moderation, and conditional process modeling; 2012. Available from http://www.afhayes.com/public/process2012.pdf. Accessed September 4, 2021.

53. Lee KH, Hyun SS. The effects of tourists' knowledge-sharing motivation on online tourist community loyalty: the moderating role of ambient stimuli. Curr Issues Tour. 2018;21(13):1521-1546. doi:10.1080/13683500.2016.1145197

54. Ben-Shaul M, Reichel A. Motives, modes of participation, and loyalty intentions of Facebook tourism brand page consumers. J Travel Res. 2018;57(4):453-471. doi:10.1177/0047287517704087
55. Peng W, Guisheng H, Lei Y. Evolutionary game analysis of knowledge sharing of users in social Q\&A community based on knowledge quality \& quantity. Mod Intelligence. 2018;4:44-51+59.

56. Hau YS, Kang M. Extending lead user theory to users' innovationrelated knowledge sharing in the online user community: the mediating roles of social capital and perceived behavioral control. Int J Inf Manage. 2016;36(4):520-530. doi:10.1016/j.ijinfomgt.2016.02.008

57. Kwahk KY, Park DH. The effects of network sharing on knowledge-sharing activities and job performance in enterprise social media environments. Comput Human Behav. 2016;55:826-839. doi:10.1016/j.chb.2015.09.044

58. Leonardi PM. Social media, knowledge sharing, and innovation: toward a theory of communication visibility. Inf Syst Res. 2014;25 (4):796-816. doi:10.1016/j.im.2008.06.007

59. Soto-Acosta P, Popa S, Palacios-Marqués D, et al. Social web knowledge sharing and innovation performance in knowledge-intensive manufacturing SMEs. J Technol Transf. 2017;42(2):425-440. doi:10.1007/s10961-016-9498-Z

60. $\mathrm{Xu}$ J, Thaldumrong P. Factors affecting property purchase decision of Chinese people: a study of condominium marketing Thailand. Chin J Soc Sci Manag. 2018;2(1):37-50.

61. Jibril AB, Kwarteng MA, Chovancova M, Pilik M. The impact of social media on consumer-brand loyalty: a mediating role of online based-brand community. Cogent Bus Manag. 2019;6(1):1673640. doi:10.1080/23311975.2019.1673640

62. Javed M, Tučková Z, Jibril AB. The role of social media on tourists' behavior: an empirical analysis of millennials from the Czech Republic. Sustainability. 2020;12(18):7735. doi:10.3390/su12187735
Psychology Research and Behavior Management

\section{Publish your work in this journal}

Psychology Research and Behavior Management is an international, peer-reviewed, open access journal focusing on the science of psychology and its application in behavior management to develop improved outcomes in the clinical, educational, sports and business arenas. Specific topics covered in the journal include: Neuroscience, memory and decision making; Behavior modification and management; Clinica applications; Business and sports performance management; Social and developmental studies; Animal studies. The manuscript management system is completely online and includes a very quick and fair peer-review system, which is all easy to use. Visit http://www dovepress.com/testimonials.php to read real quotes from published authors. 